\title{
PENGARUH PERLAKUAN HIDRASI-DEHIDRASI TERHADAP BERBAGAI TINGKAT KEMUNDURAN PERKECAMBAHAN BENIH DAMAR (Agathis loranthifolia F. Salisb) DAN MAHONI (Swietenia macrophylla King)
}

The Effect of Priming Treatment on Various Deterioration Level in the Declining Germination Capacity of Dammar (Agathis loranthifolia F. Salisb) and Mahogany

(Swietenia macrophylla King) Seeds

\section{Zanzibar dan/and Safrudin Mokodompit}

Balai Penelitian Teknologi Perbenihan Bogor

Jl. Pakuan Ciheuleut PO. BOX 105, Bogor - 16001

Telp./Fax. (0251) 327768

Naskah masuk : 14 Februari 2006 ; Naskah diterima : 20 April 2007

\begin{abstract}
Seed deterioration of seed impossible to stop but it can be delayed. One way to do such delay is through a hydration-dehydration (priming) treatment. Priming principle is to activate internal and external resources in order to maximizing germination growth through control of imbibition rate by seed embryo. The objective of this study is to determine the effect of priming as invigoration treatment on germination capacity of dammar (Agathis loranthifolia F. Salisb) and mahogany (Swietenia macrophylla King) seeds at various degeneration levels. A completely randomized design with factorial experiments was used in which accelerated ageing (A) and priming $(B)$ is as main factors. The ageing was done through exposing the seeds to methanol vapor for 5 minutes, followed by exposure to superheated steam for 10 minute. The ageing levels, i.e. 8 and 16 times. Meanwhile, priming was done in PEG -5 bar, PEG - 10 bar, $\mathrm{KNO}_{3}-5 \mathrm{bar}, \mathrm{KNO}_{3}-10$ bar, kitchen ash, and saw dust. It turned out that osmo-conditioning on fresh dammar seed has an affect to decrease their germination capacity, but on the deteriorated seeds (with priming/ageing) did effect positively germination capacity. The optimal osmo-conditioning for dammar seed was $P E G-5$ bar or $\mathrm{KNO}_{3}-5$ bar subjected after storage and prior to sowing. Treatment of PEG -5 bar on mahogany increased germination of the seeds derived from all deterioration treatments. This treatment was applied before sowing or before seed storage. However, increasing trends in seed germination occured at osmoconditioning higher than - 5 bar. The use of kitchen ash and saw dust $(<600 \mu \mathrm{m})$ as matri-conditioning treatmens especially for mahogany give negative effect on seed germination.
\end{abstract}

Key words : priming, accelerated ageing, seed deterioration, germination capacity, mahogany and dammar seed 


\begin{abstract}
ABSTRAK
Kemunduran benih tidak dapat dihentikan tetapi hanya dapat dihambat. Salah satu cara menghambat kemunduran benih adalah perlakuan hidrasi-dehidrasi (priming). Prinsip priming adalah mengaktifkan sumber daya internal dan sumber daya eksternal dalam memaksimumkan pertumbuhan kecambah melalui laju pengaturan penyerapan air oleh embrio. Tujuan dari penelitian ini adalah mengetahui pengaruh priming sebagai perlakuan invigorasi terhadap kemampuan perkecambahan beberapa tingkat kemunduran benih pada jenis damar dan mahoni. Penelitian ini dianalisis menggunakan rancangan acak lengkap faktorial, faktor utama adalah pengusangan/tingkat kemunduran (A) dan priming (B). Pengusangan benih dilakukan dengan memberikan uap etanol selama 5 menit, kemudian dengan udara panas selama 10 menit. Taraf pengusangan adalah 0,16 dan 18 kali, sedangkan taraf priming adalah PEG -5 bar, $\mathrm{PEG}-10$ bar, $\mathrm{KNO}_{3}-5$ bar, $\mathrm{KNO}_{3}-10$ bar, abu dapur dan serbuk gergaji. Hasil penelitian menunjukkan bahwa osmokonditioning benih segar pada jenis damar berpengaruh buruk terhadap perkecambahan, namun berpengaruh baik pada benih yang telah mengalami kemunduran. Priming yang tepat pada benih ini menggunakan PEG -5 bar, juga dapat menggunakan $\mathrm{KNO}_{3}-5$ bar, dilakukan setelah benih mengalami penyimpanan yaitu sesaat sebelum penaburan. Perlakuan PEG - 5 bar pada jenis mahoni mampu meningkatkan kapasitas perkecambahan pada semua tingkat kemunduran (perlakuan terbaik), yaitu dilakukan sebelum penanaman atau sebelum penyimpanan. Terdapat kecenderungan peningkatan perkecambahan pada penggunaan osmotikum tekanan tinggi $(<-5$ bar). Penggunaan abu dapur dan serbuk gergaji $(<600 \mu \mathrm{m})$ sebagai perlakuan matrikonditioning, khususnya pada benih mahoni berpengaruh negatif terhadap perkecambahan.
\end{abstract}

\title{
Kata Kunci : priming, pengusangan, kemunduran benih, kapasitas perkecambahan, benih mahoni dan damar
}

\section{PENDAHULUAN}

Benih mempunyai batasan umur, artinya benih akan mengalami penuaan dan akhirnya mati. Peristiwa penurunan kondisi benih disebut deteroriasi atau kemunduran benih. Indikasi kemunduran benih ditandai dengan meningkatnya kandungan lipid peroksida yang merusak integritas membran. Upaya meminimalkan peroksidasi lipid dapat dilakukan melalui, modifikasi lipid, perlakuan tekanan oksigen, pemberian antioksidan dan perlakuan hidrasi-dehidrasi (priming). Prinsip priming adalah mengaktifkan sumber daya yang dimiliki benih (internal) ditambah dengan sumber daya dari luar (eksternal) untuk memaksimumkan perbaikan pertumbuhan dari hasil tanaman. Priming akan memberikan perbaikan fisiologi, antara lain benih akan berkecambah lebih cepat dan serempak, serta dapat meningkatkan persentase perkecambahannya (Ilyas 1995, Bailly et al., 1998).

Priming dapat dilakukan melalui dua cara, yaitu osmokonditioning dan matrikonditioning. Cara osmokonditioning melalui pengkondisian benih dalam larutan osmotikum, sedangkan matrikonditioning melalui pengkondisian benih dalam media padatan basah. Menurut Risdianto et al (1997), osmokonditioning menggunakan PEG (polyethylen glycol) $6000-5$ bar dan $\mathrm{KNO}_{3}$ (potasium nitrate) - 10 bar pada benih gmelina mampu meningkatkan potensi tumbuh maksimum, daya berkecambah serta kecepatan tumbuh. Perlakuan PEG dan $\mathrm{KNO}_{3}$ pada tekanan osmotikum yang tepat lebih mengaktifkan semua potensi embrio sehingga proses perkecambahan dapat berlangsung dengan sempurna serta menghasilkan kecambah yang lebih baik. Damayanti (1994) menyatakan matrikonditioning dengan air pada benih bunga matahari yang belum mengalami penyimpanan mampu meningkatkan potensi tumbuh maksimum, daya berkecambah dan kecepatan tumbuh relatif.

Priming juga dikenal sebagai salah satu perlakuan invigorasi, dapat dilakukan pada saat sebelum tanam (presowing treatment) untuk memperbaiki kinerja tanaman di lapangan, sebelum penyimpanan (prestorage treatment) untuk meningkatkan daya simpan dan kinerja lapang serta ditengah periode simpan (midstorage treatment) untuk memperbaiki vigor, viabilitas dan produktivitas 
(Basu, 1994). Benih damar dan mahoni memiliki watak semi rekalsitran karena sifat-sifatnya yang cenderung menyukai keadaan sejuk dan agak lembab (King dan Roberts, 1979, Ekanti dan Erizal, 1990, Sagala dan Endah E.S, 1990). Benih yang berwatak demikian tidak dapat disimpan lama pada suhu dan kelembaban tinggi, misalnya pada suhu kamar. Pada benih-benih yang periode simpannya pendek, untuk meningkatkan daya simpan diperlukan perlakuan invigorasi, adanya informasi bahwa priming dapat memperlambat proses kemunduran memberikan suatu kemungkinan untuk mengatasi rendahnya daya simpan benih damar dan mahoni.

Penelitian ini bertujuan mengetahui pengaruh priming (osmokonditioning dan matrikonditioning) sebagai perlakuan invigorasi terhadap kemampuan perkecambahan beberapa tingkat kemunduran benih pada jenis damar dan mahoni.

\section{BAHAN DAN METODE}

Penelitian ini dilaksanakan di laboratorium dan rumah kaca Balai Litbang Teknologi Perbenihan Bogor dan Laboratorium Ilmu dan Teknologi Benih, IPB yang berlangsung pada Juli hingga Desember 2005. Selain benih, bahan dan alat yang digunakan adalah $\mathrm{KNO}_{3}$, PEG 6000, abu dapur, serbuk gergaji, kertas merang, alkohol, media perkecambahan (tanah dan pasir), mesin pengusang cepat (MPC IPB 77-1), bak kecambah, sprayer.

Seleksi untuk mendapatkan benih bervigor awal seragam, dilakukan dengan memilih benih yang bernas, tidak keriput dan warna kulit yang seragam. Ciri-ciri spesifik benih hasil seleksi untuk jenis damar adalah: lonjong, berisi, dan berwarna coklat, sedangkan untuk jenis mahoni : berbentuk pipih, coklat dan mengkilat.

Untuk mendapatkan variasi vigor yang menunjukkan tingkat kemunduran dilakukan pengusangan dengan mesin pengusang cepat (MPC IPB 77-1). Perlakuan pengusangan dilakukan dengan cara : 5 menit menaikan uap etanol dan 10 menit dengan uap panas. Taraf pengusangan terdiri dari 0,8 dan 16 kali. Semakin tinggi taraf pengusangan diasumsikan benih memiliki tingkat kemunduran yang tinggi.

Priming dengan osmokonditioning menggunakan larutan $\mathrm{PEG}, \mathrm{KNO}_{3}$, sedangkan perlakuan matrikonditioning menggunakan abu dapur dan serbuk gergaji. Formula PEG 6000 dihitung berdasarkan rumus Michel (1988) sebagai berikut :

$$
\begin{aligned}
& \left\{4-(5,16 ¥ \mathrm{~T}-560 ¥+16)^{0,5}\right\} \\
& {[\mathrm{PEG}]=\longrightarrow \ldots \ldots \ldots \ldots \ldots \ldots . . . .(\mathrm{I})} \\
& (2,5 \mathrm{~T}-280)
\end{aligned}
$$

dimana :

$$
\begin{aligned}
{[\mathrm{PEG}] } & \left.=\text { Konsentrasi PEG (gram PEG } / \text { gram } \mathrm{H}_{2} \mathrm{O}\right) \\
¥ & =\text { Potensial osmotik larutan }(\text { Bar }) \\
\mathrm{T} & =\text { Suhu ruangan }\left({ }^{\mathrm{O}} \mathrm{C}\right) \\
1 \mathrm{Bar} & =10^{-1} \mathrm{Mpa}
\end{aligned}
$$


Formula $\mathrm{KNO}_{3}$ digunakan rumus Vant Holff dalam Wilkins (1990), yaitu :

$$
P=\frac{-(\mathrm{m} / \mathrm{BM}) \mathrm{R} \mathrm{T}}{\mathrm{V}}
$$

dimana :

$$
\begin{aligned}
\mathrm{P} & =\text { Potensial osmotik } \\
\mathrm{m} & =\text { Massa } \mathrm{KNO}_{3}(\text { gram }) \\
\mathrm{T} & =\text { Suhu mutlak }\left({ }^{\mathrm{O}} \mathrm{K}\right) \\
\mathrm{V} & =\text { Volume }(\text { liter }) \\
\mathrm{R} & =0,0821 \\
\mathrm{BM} & =\text { Berat molekul }
\end{aligned}
$$

Penelitian ini menggunakan Rancangan Acak Lengkap (RAL), terdiri dari 2 faktor yaitu : (A) tingkat kemunduran/pengusangan : $\mathrm{A}_{1}=0$ menit (kontrol), $\mathrm{A}_{2}=8 \mathrm{kali}, \mathrm{A}_{3}=16$ kali dan (B) priming : $\mathrm{B}_{1}=$ kontrol, $\mathrm{B}_{2}=\mathrm{PEG}-5$ bar, $\mathrm{B}_{3}=\mathrm{PEG}-10$ bar, $\mathrm{B}_{4}=\mathrm{KNO}_{3}-5$ bar, $\mathrm{B}_{5}=\mathrm{KNO}_{3}-10$ bar, $\mathrm{B}_{6}=\mathrm{Abu}$ dapur, $\mathrm{B}_{7}=$ serbuk gergaji.

PEG - 5 bar diperoleh dengan cara melarutkan PEG sebanyak 197,82 gram ke dalam gelas piala yang telah berisi 1000 gram $\mathrm{H}_{2} \mathrm{O}$ (persamaan I), lalu diaduk hingga rata. Benih kemudian direndam ke dalam larutan, setiap 3 jam diaduk agar kebutuhan oksigen terpenuhi serta untuk mempercepat proses imbibisi (damar $=5$ hari, mahoni $=2$ hari). Perendaman dihentikan sehari sebelum radikel muncul. Setelah waktu perendaman tercapai kemudian benih dikering anginkan dan setiap jam kelompok benih ditimbang beratnya hingga mencapai berat awal (sebelum perendaman). Jumlah PEG untuk konsentrasi - 10 bar adalah 286, 979 gram, sedangkan untuk $\mathrm{KNO}_{3}-5$ bar dan 10 bar, masing-masing 20,50 gram dan 41,01 gram (persamaan II). Perbandingan berat antara abu dapur/serbuk gergaji : benih : air $(0,4: 1: 1)$. Ukuran abu dapur dan serbuk gergaji adalah yang lolos pada saringan $600 \mu \mathrm{m}$ (mikrometer) $=28$ mesh.

Media tabur yang digunakan adalah campuran tanah dan pasir dengan perbandingan $1: 1$ (v/v). Perkecambahan dilakukan di rumah kaca. Ulangan dilakukan sebanyak4 kali@25 butir. Analisis data menggunakan program SAS, (1985) melalui Uji F (Anova). Apabila uji F nyata maka dilanjutkan dengan uji berganda Duncan. Parameter pengamatan terdiri dari : daya berkecambah (DB), keserempakan $\left(\mathrm{KS}_{\mathrm{t}}\right)$ dan kecepatan tumbuh $\left(\mathrm{KC}_{\mathrm{t}}\right)$.

\section{HASIL DAN PEMBAHASAN}

Rekapitulasi hasil perhitungan sidik ragam tertera pada Tabel 1. Berdasarkan Tabel 1, semua faktor tunggal yaitu pengusangan (A), dan priming (B) berpengaruh nyata pada semua tolok ukur perkecambahan ke dua jenis, demikian halnya interaksi faktor $(\mathrm{AB})$ pada benih mahoni, sedangkan pada benih damar interaksi hanya ditunjukkan pada keserempakan tumbuh $\left(\mathrm{KS}_{\mathrm{t}}\right)$. Nilai rata-rata pengaruh faktor tunggal disajikan pada Gambar 1 - 4, sedangkan hasil uji berganda Duncan dari interaksi faktor dapat dilihat pada Tabel 2 dan 3. 
Tabel (Table) 1. Rekapitulasi Sidik Ragam (Uji F) Pengaruh Pengusangan dan Priming Terhadap Perkecambahan Benih Damar dan Mahoni ( Summarized analysis of variance referring to ageing and priming on the germination of dammar and mahogany seeds )

\begin{tabular}{|c|c|c|c|c|}
\hline \multirow[t]{2}{*}{$\begin{array}{c}\text { Jenis } \\
\text { (seed species) }\end{array}$} & \multirow{2}{*}{$\begin{array}{l}\text { Tolok ukur kriteria } \\
\text { perkecambahan } \\
\text { benih (seed } \\
\text { germination) }\end{array}$} & \multicolumn{3}{|c|}{$\begin{array}{l}\text { Nilai peluang perlakuan } \\
\text { (Value of treatments probability) }\end{array}$} \\
\hline & & $\begin{array}{c}\text { Pengusangan } \\
\text { (ageing), A }\end{array}$ & $\begin{array}{l}\text { Hidrasi - Dehidrasi } \\
\text { (priming) }\end{array}$ & $\begin{array}{c}\text { Interaksi } \\
\text { (interaction), } \mathrm{AB}\end{array}$ \\
\hline \multirow[t]{3}{*}{ Damar } & DB $(\%)$ & $0.0001(* *)$ & $0.0055(* *)$ & 0.7918 (ns) \\
\hline & $\mathrm{KS}_{\mathrm{t}}(\%)$ & $0.0001(* *)$ & $0.0001(* *)$ & $0.0358(*)$ \\
\hline & $\mathrm{KC}_{\mathrm{t}}$ (etmal) & $0.0001(* *)$ & $0.0001(* *)$ & 0.3902 (ns) \\
\hline \multirow[t]{3}{*}{ Mahoni } & DB $(\%)$ & $0.0001(* *)$ & $0.0001(* *)$ & $0.0001(* *)$ \\
\hline & $\mathrm{KS}_{\mathrm{t}}(\%)$ & $0.0001(* *)$ & $0.0001(* *)$ & $0.0001(* *)$ \\
\hline & $\mathrm{KC}_{\mathrm{t}}$ (etmal) & $0.0001(* *)$ & $0.0001(* *)$ & $0.0036(* *)$ \\
\hline
\end{tabular}

Keterangan (Remarks) :

$\mathrm{DB} \quad=$ persentase perkecambahan (germination percentage)

$\mathrm{KS}_{\mathrm{t}} \quad=$ keserempakan tumbuh (growth simultanity)

$\mathrm{KC}_{\mathrm{t}} \quad=$ kecepatan tumbuh (growth rate)

** = berpengaruh nyata (significant effect), $\mathrm{P}=99 \%$

ns $\quad=$ tidak berpengaruh nyata (no significant effect)

Benih damar lebih tahan diusangkan dibandingkan benih mahoni (Gambar 1 - 4), namun respon ini tidak mencerminkan daya simpan benih secara alami. Ekanti dan Erizal (1990), menyimpan benih mahoni $\left(\mathrm{KA}=4 \%, \mathrm{t}=25-27^{\circ} \mathrm{C}\right)$, setelah 60 minggu benih belum kehilangan viabilitasnya. Hal sebaliknya Sagala dan Endah S.R (1990), melaporkan bahwa pada kondisi yang sama penyimpanan benih damar selama 3 bulan menyebabkan kehilangan semua viabilitasnya. Schmidt (2000), kemunduran umumnya terjadi selama periode panjang dan selama itu terjadi kerusakankerusakan sitologi dan biokimia. Kerusakan yang disebabkan oleh suhu atau mekanis tidak digolongkan ke dalam proses kemunduran dimaksud. 
Tabel (Table) 2. Hasil Uji Lanjut Duncan Pengaruh Pengusangan dan Priming terhadap Perkecambahan Benih Damar ( Results of Duncan's multiple range test referring to the effect of ageing and priming on the germination of dammar seed)

\begin{tabular}{|c|c|c|c|c|c|c|}
\hline \multirow{2}{*}{$\begin{array}{c}\text { Kombinasi } \\
\text { Perlakuan } \\
\text { (Treatments } \\
\text { combination) }\end{array}$} & \multicolumn{3}{|c|}{$\begin{array}{l}\text { Karakteristik Perkecambahan } \\
\text { (Germination characteristic) }\end{array}$} & \multicolumn{3}{|c|}{$\begin{array}{l}\text { Peningkatan/Kehilangan Viabilitas } \\
\text { (Increasing/loss of Viability) }\end{array}$} \\
\hline & DB (\%) & $\mathrm{KS}_{\mathrm{t}}(\%)$ & $\begin{array}{c}\mathrm{KC}_{\mathrm{t}} \\
(\text { Etmal })\end{array}$ & DB (\%) & $\mathrm{KS}_{\mathrm{t}}(\%)$ & $\mathrm{KC}_{\mathrm{t}}($ Etmal $)$ \\
\hline $\mathrm{A}_{1} \times \mathrm{B}_{1}$ & 92.00 & $88.00 \mathrm{a}$ & 1.38 & 0,00 & 0,00 & 0,00 \\
\hline $\mathrm{A}_{1} \times \mathrm{B}_{2}$ & 92.00 & $82.67 \mathrm{ab}$ & 1.37 & 0,00 & $-5,33$ & -0.72 \\
\hline $\mathrm{A}_{1} \times \mathrm{B}_{3}$ & 90.67 & $81.33 \mathrm{abc}$ & 1.34 & $+1,33$ & $-6,67$ & -2.90 \\
\hline $\mathrm{A}_{1} \times \mathrm{B}_{4}$ & 88.00 & $78.67 \mathrm{bcd}$ & 1.30 & $-4,00$ & $-9,33$ & -5.80 \\
\hline $\mathrm{A}_{1} \times \mathrm{B}_{5}$ & 88.00 & $82.67 \mathrm{ab}$ & 1.31 & $-4,00$ & 0,00 & -5.07 \\
\hline $\mathrm{A}_{1} \times \mathrm{B}_{6}$ & 84.00 & 74.67 bcde & 1.24 & $-8,00$ & $-8,00$ & -10.14 \\
\hline $\mathrm{A}_{1} \times \mathrm{B}_{7}$ & 84.00 & $70.67 \mathrm{def}$ & 1.23 & $-8,00$ & $-17,33$ & -10.87 \\
\hline $\mathrm{A}_{2} \mathrm{XB}_{1}$ & 77.33 & $70.67 \mathrm{def}$ & 1.12 & 0,00 & 0,00 & 0,00 \\
\hline $\mathrm{A}_{2} \mathrm{XB}_{2}$ & 85.33 & $78.67 \mathrm{bcd}$ & 1.27 & $+8,00$ & $+8,00$ & +13.39 \\
\hline $\mathrm{A}_{2} \times \mathrm{B}_{3}$ & 73.33 & $73.33 \mathrm{cdef}$ & 1.20 & 0,00 & $+2,66$ & +7.14 \\
\hline $\mathrm{A}_{2} \mathrm{xB}_{4}$ & 81.33 & 74.67 bcde & 1.20 & $+4,00$ & $+4,00$ & +7.14 \\
\hline $\mathrm{A}_{2} \times \mathrm{B}_{5}$ & 84.00 & $78.87 \mathrm{bcd}$ & 1.24 & $+6,67$ & $+8,20$ & +10.71 \\
\hline $\mathrm{A}_{2} \mathrm{xB}_{6}$ & 77.33 & $70.67 \mathrm{def}$ & 1.14 & 0,00 & 0,00 & +1.79 \\
\hline $\mathrm{A}_{2} \mathrm{xB}_{7}$ & 77.33 & $69.33 \mathrm{ef}$ & 1.14 & 0,00 & $-1,34$ & +1.79 \\
\hline $\mathrm{A}_{3} \times \mathrm{B}_{1}$ & 69.33 & $58.67 \mathrm{~g}$ & 0.98 & 0,00 & 0,00 & 0,00 \\
\hline $\mathrm{A}_{3} \times \mathrm{B}_{2}$ & 77.33 & $72.00 \mathrm{def}$ & 1.14 & $+8,00$ & $+13,33$ & +16.33 \\
\hline $\mathrm{A}_{3} \times \mathrm{B}_{3}$ & 73.33 & $68.00 \mathrm{ef}$ & 1.08 & $+8,00$ & $+9,33$ & +10.20 \\
\hline $\mathrm{A}_{3} \mathrm{xB}_{4}$ & 73.33 & $68.00 \mathrm{ef}$ & 1.07 & $+8,00$ & $+9,33$ & +9.18 \\
\hline $\mathrm{A}_{3} \mathrm{xB}_{5}$ & 76.00 & $72.00 \mathrm{def}$ & 1.11 & $+6,67$ & $+13,33$ & +13.27 \\
\hline $\mathrm{A}_{3} \times \mathrm{B}_{6}$ & 70.67 & $65.33 \mathrm{fg}$ & 1.04 & $+1,34$ & $+6,66$ & +6.12 \\
\hline $\mathrm{A}_{3} \times \mathrm{B}_{7}$ & 70.67 & $60.00 \mathrm{~g}$ & 1.02 & $+1,34$ & $+1,33$ & +4.08 \\
\hline
\end{tabular}

Keterangan (Remarks) :

Nilai yang diikuti oleh huruf yang sama pada kolom yang sama tidak berbeda nyata : $\mathrm{a}>\mathrm{b}>\mathrm{c}<\mathrm{d}$, dst (Value followed in the same letters in the same column are not significantly different : $a>b>c<d$, etc). DB = persentase perkecambahan (germination percentage), $\mathrm{KS}_{\mathrm{t}}=$ keserempakan tumbuh (growth simultaneity), $\mathrm{KC}_{\mathrm{t}}=$ kecepatan tumbuh (growth rate) 


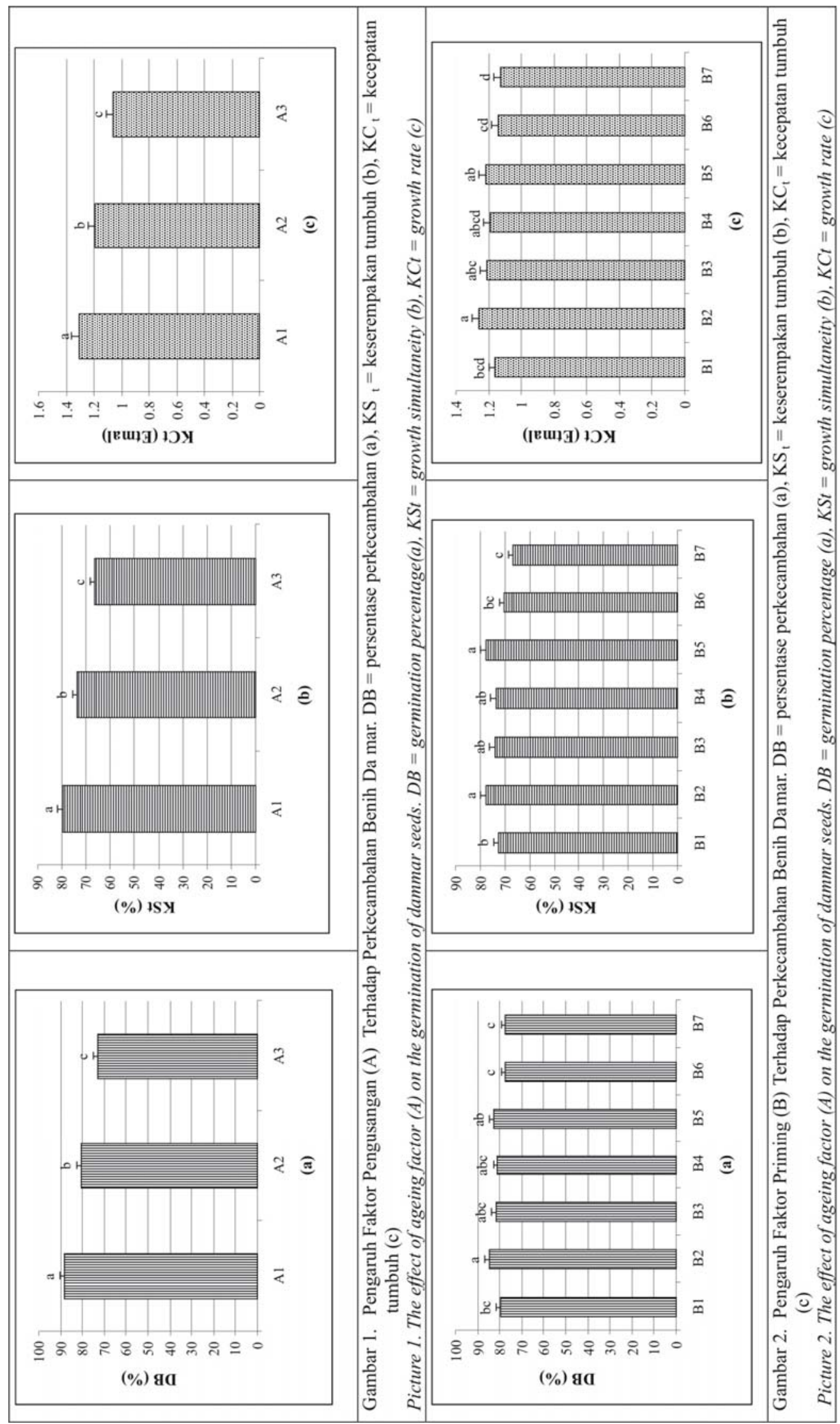




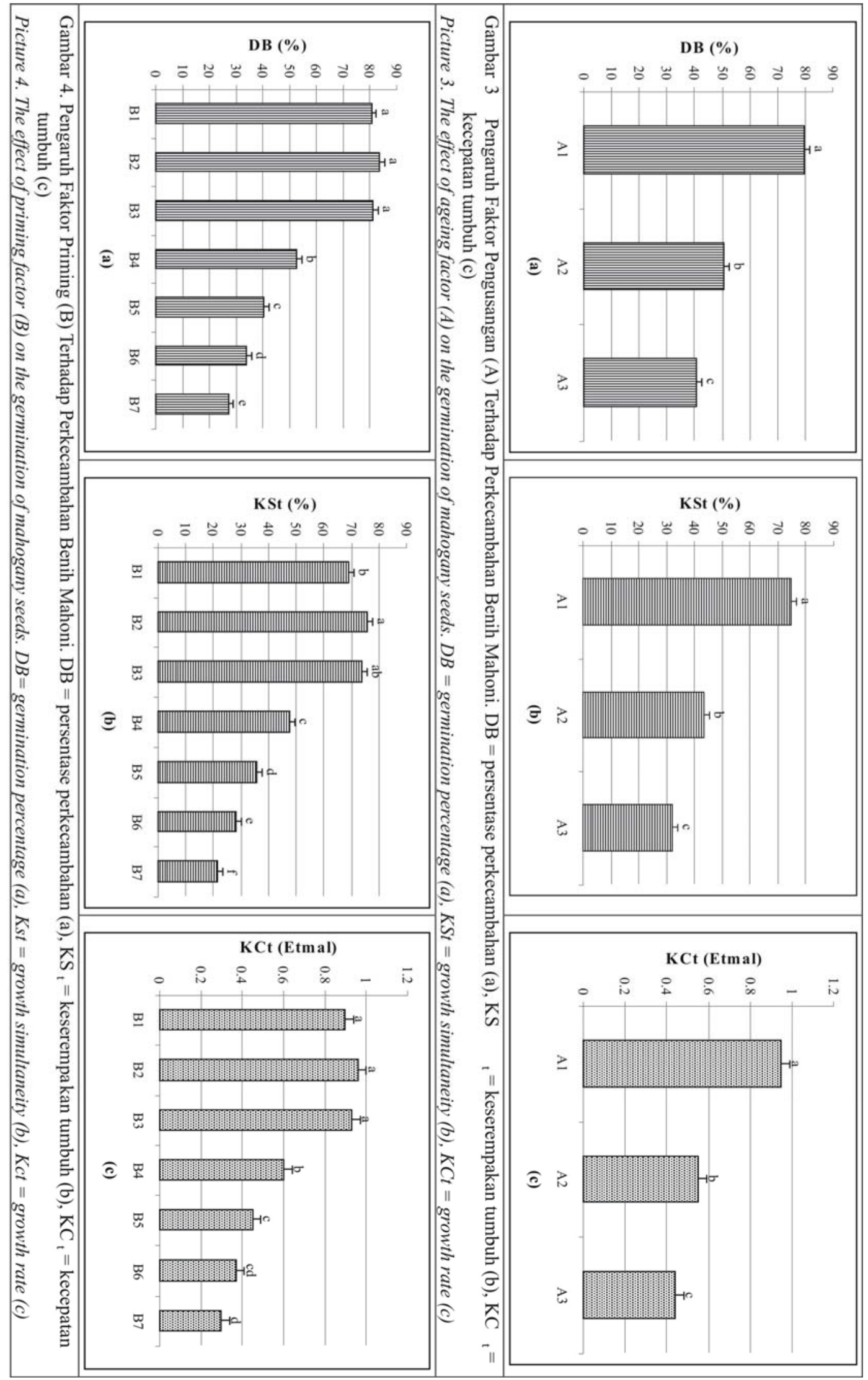


Tabel (Table) 3. Hasil Uji Lanjut Duncan Pengaruh Pengusangan dan Priming terhadap Perkecambahan Benih Mahoni ( Results of Duncan's multiple range test referring to the effect of ageing and priming on the germination of mahogany seed )

\begin{tabular}{|c|c|c|c|c|c|c|}
\hline \multirow{2}{*}{$\begin{array}{l}\text { Kombinasi } \\
\text { Perlakuan } \\
\text { (Treatments } \\
\text { combination) }\end{array}$} & \multicolumn{3}{|c|}{$\begin{array}{c}\text { Karakteristik Perkecambahan (Germination } \\
\text { characteristic) }\end{array}$} & \multicolumn{3}{|c|}{$\begin{array}{l}\text { Peningkatan/Kehilangan Viabilitas } \\
\text { (Increasing/loss of Viability) }\end{array}$} \\
\hline & DB (\%) & $\mathrm{KS}_{\mathrm{t}}(\%)$ & $\begin{array}{c}\mathrm{KC}_{\mathrm{t}} \\
(\text { Etmal) }\end{array}$ & DB (\%) & $\mathrm{KS}_{\mathrm{t}}(\%)$ & $\mathrm{KC}_{\mathrm{t}}(\mathrm{Etmal})$ \\
\hline $\mathrm{A}_{1} \times \mathrm{B}_{1}$ & $93.33 \mathrm{ab}$ & $90.67 \mathrm{a}$ & $1.00 \mathrm{ab}$ & 0,00 & 0,00 & 0,00 \\
\hline $\mathrm{A}_{1} \times \mathrm{B}_{2}$ & $94.67 \mathrm{a}$ & $92.00 \mathrm{a}$ & $1.14 \mathrm{a}$ & $+1,34$ & $+2,67$ & $+14,00$ \\
\hline $\mathrm{A}_{1} \times \mathrm{B}_{3}$ & $93.33 \mathrm{ab}$ & $72.00 \mathrm{~cd}$ & $1.13 \mathrm{a}$ & 0.00 & $-18,67$ & $+13,00$ \\
\hline $\mathrm{A}_{1} \mathrm{xB}_{4}$ & $81.33 b c$ & $78.67 b c$ & $0.98 \mathrm{bc}$ & $-12,00$ & $-12,00$ & $+2,00$ \\
\hline $\mathrm{A}_{1} \times \mathrm{B}_{5}$ & $72.00 \mathrm{cde}$ & $69.33 \mathrm{cde}$ & $0.85 \mathrm{cde}$ & $-21,35$ & $-21,34$ & $-15,00$ \\
\hline $\mathrm{A}_{1} \times \mathrm{B}_{6}$ & $65.33 \mathrm{ef}$ & $57.33 \mathrm{fgh}$ & $0.76 \mathrm{def}$ & $-28,00$ & $-33,34$ & $-24,00$ \\
\hline $\mathrm{A}_{1} \times \mathrm{B}_{7}$ & $57.33 \mathrm{f}$ & $49.33 \mathrm{~h}$ & $0.65 \mathrm{f}$ & $-36,00$ & $-47,34$ & $-35,00$ \\
\hline $\mathrm{A}_{2} \times \mathrm{B}_{1}$ & $80.00 \mathrm{~cd}$ & $68.00 \mathrm{cdef}$ & $0.87 \mathrm{cde}$ & 0,00 & 0,00 & 0,00 \\
\hline $\mathrm{A}_{2} \mathrm{XB}_{2}$ & $81.33 \mathrm{~cd}$ & $73.33 \mathrm{c}$ & $0.90 \mathrm{~cd}$ & $+1,33$ & $+5,33$ & +19.54 \\
\hline $\mathrm{A}_{2} \times \mathrm{B}_{3}$ & $78.67 \mathrm{~cd}$ & $72.00 \mathrm{~cd}$ & $0.88 \mathrm{cde}$ & $-1,33$ & $+4,00$ & +1.14 \\
\hline $\mathrm{A}_{2} \times \mathrm{B}_{4}$ & $45.33 \mathrm{~g}$ & $37.33 \mathrm{i}$ & $0.48 \mathrm{~g}$ & - 34,67 & $-30,67$ & -44.82 \\
\hline $\mathrm{A}_{2} \mathrm{xB}_{5}$ & $30.67 \mathrm{~h}$ & $24.00 \mathrm{jk}$ & $0.32 \mathrm{~h}$ & $-49,33$ & $-44,00$ & -44.82 \\
\hline $\mathrm{A}_{2} \times \mathrm{B}_{6}$ & $24.00 \mathrm{hi}$ & $20.00 \mathrm{jkl}$ & $0.25 \mathrm{~h}$ & $-56,00$ & $-48,00$ & -71.26 \\
\hline $\mathrm{A}_{2} \times \mathrm{B}_{7}$ & $14.67 \mathrm{ij}$ & $9.33 \mathrm{~lm}$ & $0.15 \mathrm{ij}$ & 65,33 & $-58,67$ & -82.75 \\
\hline $\mathrm{A}_{3} \mathrm{xB}_{1}$ & $68.00 \mathrm{def}$ & $52.00 \mathrm{gh}$ & $0.72 \mathrm{ef}$ & 0,00 & 0,00 & 0,00 \\
\hline $\mathrm{A}_{3} \times \mathrm{B}_{2}$ & 74.67 cde & $61.33 \mathrm{defg}$ & $0.82 \mathrm{cde}$ & $+6,67$ & $+9,33$ & +13.99 \\
\hline $\mathrm{A}_{3} \mathrm{XB}_{3}$ & $70.67 \mathrm{cde}$ & $58.67 \mathrm{efgh}$ & $0.79 \mathrm{def}$ & $+2,67$ & $+6,67$ & +9.72 \\
\hline $\mathrm{A}_{3} \times \mathrm{B}_{4}$ & $30.67 \mathrm{~h}$ & $26.67 \mathrm{j}$ & $0.33 \mathrm{~h}$ & $-37,33$ & $-25,33$ & -54.16 \\
\hline $\mathrm{A}_{3} \times \mathrm{B}_{5}$ & $18.67 \mathrm{hij}$ & $13.33 \mathrm{klm}$ & 0.19 hij & $-49,33$ & $-38,67$ & -73.61 \\
\hline $\mathrm{A}_{3} \times \mathrm{B}_{6}$ & $12.00 \mathrm{j}$ & $20.00 \mathrm{jkl}$ & $0.11 \mathrm{ij}$ & $-56,00$ & $-32,00$ & -84.72 \\
\hline $\mathrm{A}_{3} \mathrm{xB}_{7}$ & $9.33 \mathrm{j}$ & $5.33 \mathrm{~m}$ & $0.09 \mathrm{j}$ & $-58,67$ & $-46,67$ & -87.5 \\
\hline
\end{tabular}

Keterangan (Remarks) :

Nilai yang diikuti oleh huruf yang sama pada kolom yang sama tidak berbeda nyata : $\mathrm{a}>\mathrm{b}>\mathrm{c}<\mathrm{d}$, dst (Value followed in the same letters in the same column are not significantly different : $a>b>c<d$, etc), DB = persentase perkecambahan (germination percentage), $\mathrm{KS}_{\mathrm{t}}=$ keserempakan tumbuh (growth simultanity), $\mathrm{KC}_{\mathrm{t}}=$ kecepatan tumbuh (growth rate)

Kondisi kulit sangat menentukan percepatan imbibisi ke dalam benih. Kulit benih damar relatif berkayu, sedangkan benih mahoni lebih lunak (bergabus) sehingga waktu imbibisi pada benih damar relatif lebih lama. Pada prakteknya, perendaman dalam larutan seharusnya dihentikan sehari sebelum radikel muncul. Hal tersebut tidak dapat dicapai karena perendaman yang lebih lama menyebabkan benih menjadi rusak. Larutan dan kulit (jaringan mati) merupakan kondisi yang baik bagi pertumbuhan jamur terbawa benih dan hal tersebut terlihat selama benih direndam hingga dikecambahkan. Oleh karena itu, sebelum dilakukan priming terlebih dahulu benih disterilkan, atau menambahkan desinfektan pada larutan osmotikum. Waktu perendaman dalam larutan pada benih damar selama 5 hari, sedangkan benih mahoni selama 2 hari. Keberhasilan perlakuan osmoconditioning menurut Heydecker dan Gibbins dalam Veazie dan Cantlife (1984) ditentukan oleh lamanya imbibisi, suhu imbibisi dan tekanan potensial larutan osmotikum. 
Priming pada benih segar berpengaruh negatif pada benih damar, penurunan kapasitas perkecambahan tertinggi diperoleh pada perlakuan $a_{1} b_{7}$, parameter keserempakan tumbuh $(-17 \%)$. Pada benih yang telah diusangkan semua perlakuan mampu meningkatkan kapasitas perkecambahan, tertinggi diperoleh perlakuan $a_{3} b_{2}(16 \%)$, parameter kecepatan tumbuh. Hal ini mengindikasikan bahwa perlakuan priming pada benih damar hanya baik bila dilakukan setelah benih tersebut mengalami penyimpanan yaitu sesaat sebelum penaburan. Menurut Roberts (1972), pada beberapa benih yang masih vigor, perlakuan priming tidak menunjukkan pengaruhnya dan kadang dapat menghambat perkecambahan karena masih memiliki masih enzim-enzim, organel sel dan cadangan makanan yang relatif baik.

Priming benih segar jenis mahoni, kecuali perlakuan PEG - 5 bar semua berpengaruh negatif terhadap perkecambahan. Pada perlakuan ini, kecepatan tumbuh benih menjadi kecambah normal dapat ditingkatkan sebesar $14 \%$. Secara umum, penggunaan priming dengan PEG (- 5 dan - 10 bar) selalu meningkatkan kapasitas perkecambahan utamanya pada parameter keserempakkan dan kecepatan tumbuh. Dengan demikian, priming dengan PEG pada benih mahoni dapat dilakukan sebelum penanaman dan atau sebelum penyimpanan. Penelitian Basu (1994) menunjukkan bahwa benih wortel (Daucus carota L) yang baru dipanen meningkat daya simpannya setelah diberi perlakuan priming sebelum disimpan, namun benih-benih yang lain belum tentu memiliki respon yang baik terhadap perlakuan ini. Maude (1996) dalam Schmidt (2000), priming membuat perkecambahan lebih dari sekedar imbibisi, yaitu sedekat mungkin pada fase ke tiga, yaitu fase perpanjangan akar. Selama priming keragaman dalam tingkat penyerapan awal diatasi; semua benih cenderung mencapai tingkat dimana benih siap untuk berkecambah serentak bila berada pada kondisi optimal.

Terdapat kecenderungan penggunaan osmotikum tekanan tinggi lebih baik pengaruhnya, khususnya pada benih yang memiliki tingkat kemunduran tinggi. Osmotikum tekanan tinggi memiliki daya pegang air yang rendah sehingga laju penyerapan air (imbibisi) ke dalam benih lebih cepat. Pada tingkat kemunduran tinggi secara alami aktifitas metabolisma berlangsung cepat dan pemberian air pada tekanan $<-5$ bar sesuai untuk mengkondisikan benih menjadi lebih vigor. Implikasi untuk tujuan yang luas adalah kedua benih tidak akan optimum perkecambahannya pada kondisi yang relatif kering, kebutuhan air harus selalu cukup dan tersedia dalam media. Selain itu, larutan khususnya $\mathrm{KNO}_{3}$ dapat masuk ke dalam sel-sel benih dan dapat berfungsi sebagai hara, namun penimbunan dalam jumlah besar dapat menjadi inhibitor bagi perkecambahan (Basu, 1994).

Keberhasilan priming dengan matrikonditioning sangat ditentukan oleh beberapa hal, yaitu memiliki daya pegang air yang tinggi, memiliki sistem pengantaran yang dapat diduga (predictable delivery system), memiliki kerapatan ruang yang besar sehingga dapat digunakan dalam jumlah kecil berdasarkan bobotnya, serta memiliki sifat mencampur yang baik (Khan et al, 1990). Penggunaan serbuk gergaji dan abu dapur sebagai perlakuan matrikonditioning pada penelitian ini tidak memberikan hasil yang memuaskan, khususnya pada benih mahoni. Butiran bahan matrikonditioning yang digunakan masih relatif besar $(<600 \mu \mathrm{m})$ maka akan lebih mudah menyerap dan melepaskan air sehingga perlakuan mirip dengan perendaman benih selama beberapa hari pada kondisi yang kurang menguntungkan ; atmosfir sekitar benih menjadi lebih lembab dan juga memicu pertumbuhan jamur seperti pada perlakuan osmotikum. Penggunaan matrikonditioning seperti ini lebih tepat diaplikasikan pada benih yang kulitnya impermeabel terhadap air dan udara. Selain itu, pengeringan kembali (Lukazewski dan Blevins 1996, dan Bailly et al,2000) setelah matrikonditioning mengakibatkan asam askarbonat yang tertimbun tidak dapat diregenerasi kembali, atau dapat pula karena terjadi peningkatan MDA (malondialdehyde) yang menunjukkan tingginya lipid peroksida dalam benih. 


\section{KESIMPULAN}

1. Perlakuan osmokonditioning pada benih damar, yaitu PEG -5 bar dan $\mathrm{KNO}_{3}-5$ bar berpengaruh baik pada benih yang telah mengalami kemunduran, diaplikasikan setelah benih disimpan yaitu sesaat sebelum penaburan.

2. Osmokonditioning dengan PEG - 5 bar pada jenis mahoni mampu meningkatkan kapasitas perkecambahan pada semua tingkat kemunduran. Penggunaannya dapat dilakukan sebelum penanaman atau sebelum penyimpanan.

3. Penggunaan osmotikum tekanan tinggi $(<-5$ bar) cenderung lebih baik meningkatkan kapasitas perkecambahan dibanding osmotikum bertekanan rendah.

4. Penggunaan abu dapur dan serbuk gergaji $(<600 \mu \mathrm{m})$ sebagai perlakuan matrikonditioning, khususnya pada benih mahoni berpengaruh negatif terhadap perkecambahan.

\section{DAFTAR PUSTAKA}

Bailly, C. A., F. Benamar, Corbineau and D. Come. 1998. Free Radical Scavenging as Affected by Accelerated Ageing and Subsequent Priming in Sunflower Seed. Physiol. Plant.104 : 646 652

. 2000. Antioxidant System in Sunflower (Helianthus annuus. L) Seed as Affected by Priming. Seed Sci, Research. 10 (1) : 35 - 42

Basu, R. N. 1994. An Apprasial of Research on Wet and Dry Physiological Seed Treatments and Their Applicability With Special Reference to Tropical and Subtropical Countries. Seed Science Technology. $22: 107-126$

Damayanti. 1994. Perubahan Kandungan Asam Lemak dan Hubungannya dengan Viabilitas Pada Benih Bunga Matahari. Skripsi Jurusan Budidaya Pertanian, Fakultas Pertanian, Institut Pertanian Bogor (Tidak diterbitkan).

Ekanti S. dan Erizal. 1990. Penentuan Suhu dan Kelembaban Nisbi Udara Selama Periode Konservasi Benih Mahoni (Swietenia macrophylla King). Balai Teknologi Perbenihan. Laporan Uji Coba No : 91 (Tidak diterbitkan)

Ilyas, S. 1995. Perubahan Fisiologis dan Biokimia Benih dalam Proses Seed Conditioning. Keluarga Benih. No : 2

Khan, A.A., H. Miura, J. Prasinki and S. Ilyas. 1990. Matriconditioning of Seed to Improve Emergence. p 19-40. Proceedings of Symposium on Stand Establisment on Holticultural Crop. Minneapolis.

King, M. W. and Robert. 1979. The Storage of Recalsitrant Seed. Castle House Publication. IBPGR. Secretariat, Rome.

Lukaszewski, K. M. and D. G. Blevins. 1996. Root Growth Inbibition in Boron Deficient or Alumunium Stressed Squash May be a Result of Impaired Ascorbate Metabolisme. Plant Physiol. 112 (3) : 1135 - 1140.

Malcolm B. Wilkins, 1990. Advanced Plant Physiology. Longman scientific and technical. New York. $514 \mathrm{pp}$

Michel , B. E. 1988. Evaluation of Water Potentials of Polyethylene Glycol 8000 both in the Absence and Presence of other Solutes. Plant Physiol. 72: 66-70. 
Risdianto, R., E. Murniati dan M. Zanzibar. 1997. Pengaruh Perlakuan Pembersihan Lubang dan Pelapisan terhadap Perkecambahan Benih Gmelina arborea Linn. Balai Teknologi Perbenihan. Bogor. Buletin Teknologi Perbenihan Vol. 4 No. 2.

Robert, E. H. 1972. Viability of seed. Chapman and Hall. London

Sagala, J dan Endah Sri Rejeki. 1990. Pengaruh Kadar Air Awal Benih, Perlakuan Asam Propimat serta Suhu dan Kelembaban Nisbi Udara Ruang Simpan Terhadap Viabilitas Benih damar (Agathis lorantifolia Salisb). Balai Teknologi Perbenihan. Laporan Uji Coba No : 97 (Tidak diterbitkan)

SAS Institute Inc. 1985. SAS user's guide : Statistics, Version 5 edition. SAS Institute Inc., Cary. NC

Schmidth, L. 2000. Penanganan Benih Tropis dan Hutan Tropis. Ditjen Rehabilitasi Lahan dan Perhutanan Sosial. Indonesia Forest Seed Project (IFSP). Jakarta

Veazie, P. dan D.J. Cantliffe. 1984. Need for High Quality Seed for Effetive Priming to Overcome Thermodormancy in Lettuce. J. Amer. Soc. Hort. Sci. 109 (3) : 365-372. 